\title{
Production of a Thermostable Lipase by Humicola lanuginosa Grown on Sorbitol-Corn Steep Liquor Medium
}

\author{
IBRAHIM Che Omar, Naomichi NishIO and Shiro NAGAI* \\ Department of Fermentation Technology, Faculty of Engineering, Hiroshima University, \\ Saijo-cho, Higashi-Hiroshima 724, Japan
}

Received February 6, 1987

\begin{abstract}
For thermostable lipase production by Humicola lanuginosa No. 3, a simple optimized medium consisting of $(\%, \mathrm{w} / \mathrm{v})$ : sorbitol, 1.0 ; corn steep liquor, $1.0 ; \mathrm{NaCl}, 0.5 ; \mathrm{CaCl}_{2} \cdot 2 \mathrm{H}_{2} \mathrm{O}, 0.01$; Silicone Km-70 (antifoamer), 0.2; and whale oil or castor oil as a lipase inducer, 0.3 , was used. The yield of the lipase was about $80 \sim 120 \mathrm{U} / \mathrm{ml}$ after $25 \mathrm{hr}$ aerobic cultivation at $45^{\circ} \mathrm{C}$ when the $\mathrm{pH}$ was maintained at 7 to 8 . The acetone powder preparation of the enzyme was most active at $\mathrm{pH} 7.0$ and $45^{\circ} \mathrm{C}$. The enzyme retained $100 \%$ activity on incubation for $20 \mathrm{hr}$ at $60^{\circ} \mathrm{C}$. The enzyme was able to hydrolyze almost all forms of natural fats tested (14 kinds), coconut oil being the most rapidly hydrolyzed.
\end{abstract}

Lipase (EC 3.1.1.3), a glycerol ester hydrolase, is widely distributed in animals, plants and microorganisms. Many organisms such as Aspergillus, ${ }^{1)}$ Rhizopus, ${ }^{2)}$ Mucor, ${ }^{3)}$ and other organisms ${ }^{4 \sim 8)}$ have been reported to be mesophilic lipase producers. From the viewpoint of application in fat industries, thermostable lipases ${ }^{9,10)}$ are more promising compared to their mesophilic counterparts. Most of the industrial applications of microbial lipases for the hydrolysis of glycerides, interesterification of fatty acid moieties and so on, basically involved the use of mesophilic enzymes. ${ }^{11)} \mathrm{We}$ were interested in finding a thermostable lipase with a broad substrate range, thus widening the scope of applications. Thus, we screened 20 thermophilic fungi for lipase producers.

The production of lipase by either mesophilic or thermophilic organisms is governed by numerous factors. For example, the lipase production by Geotrichum ${ }^{12}$ ) and Pseudomonas $^{13)}$ was effectively stimulated in the presence of triglycerides such as olive oil and groundnut oil. However, with a high concentration of triglycerides in the medium, several problems arose. Firstly, the medium formed a heterogeneous mixture which caused some difficulties on enzyme harvesting from the culture broth. Secondly, several workers ${ }^{6 \sim 8}$ observed a decrease in enzyme production due to the inhibition by excess fatty acids which were liberated during the hydrolysis of triglycerides. These problems might not be obvious in a small scale cultivation, however they may be inconvenient for industrial production. Therefore, we tried to improve the olive oil medium used previously as the basal medium, aiming to find an alternative to olive oil in the cultivation medium. In this report, we described some cultural conditions for the lipase production by Humicola lanuginosa No. $3^{14)}$ in a sorbitol-corn steep liquor (CSL) medium.

\section{MATERIALS AND METHODS}

Microorganisms. Three strains of $H$. lanuginosa, 13 species of Aspergillus, 2 species of Sporotrichum, Acremonium sp. and Mucor pusillus were kindly provided by Dr. T. Morinaga (Dept. of Ferment. Technol., Hiroshima University). All the cultures were maintained on potato dextrose agar at $4^{\circ} \mathrm{C}$.

* To whom correspondence should be addressed. 
Screening of potent producers. A loopful of an inoculum from each stock culture was inoculated into $10 \mathrm{ml}$ of basal medium consisting of $(\%, \mathrm{w} / \mathrm{v})$ : yeast extract, $1.0 ; \mathrm{NaCl}$, $0.5 ; \mathrm{CaCl}_{2} \cdot 2 \mathrm{H}_{2} \mathrm{O}, 0.01$; and olive oil, $1.0(\mathrm{v} / \mathrm{v})(\mathrm{pH} 7.0)$. After aerobic cultivation, the culture filtrate was examined for lipolytic activity according to the modified tributyrin agar method. ${ }^{15)}$

Medium optimization and cultivation. Based on the basal medium composition previously mentioned, an alternative to olive oil and the effects of other carbon sources, nitrogen sources, minerals and cultural conditions were investigated (see later). The cultivations were carried out in $100 \mathrm{ml}$ of medium $(500 \mathrm{ml}$ Sakaguchi flask) with an inoculum size of $2.5 \%(\mathrm{v} / \mathrm{v})$. All the cultures were carried out for $48 \mathrm{hr}$ unless otherwise stated.

Lipase production. For the production of lipase, cultivation was carried out in a 10 liter jar fermentor (MD 500; Marubishi Bioeng. Co., Ltd., Japan) with a working volume of 5 liters. The agitation and aeration rates were $200 \mathrm{rpm}$ and $1.0 \mathrm{vvm}$, respectively, with an inoculum size of $4.0 \%(\mathrm{v} / \mathrm{v})$. The incubation temperature was set at $45^{\circ} \mathrm{C}$.

Analyses. Lipase activity was determined by the method of Yamada and Machida ${ }^{16)}$ as described previously. ${ }^{14)}$ Growth was measured as dry weight cell mass after drying at $105^{\circ} \mathrm{C}$ to constant weight. Sorbitol was determined enzymatically using sorbitol dehydrogenase. ${ }^{17)}$ The formation of $\mathrm{NADH}$, as measured by the change in extinction at $340 \mathrm{~nm}$, was proportional to the amount of sorbitol present.

Preparation of the crude enzyme. Preparation of the crude enzyme was performed at $4{ }^{\circ} \mathrm{C}$ unless otherwise stated. For the screening test and medium optimization, the supernatant of the culture broth after centrifugation at $1,090 \times g$ for $15 \mathrm{~min}$ was used as the crude enzyme solution. In the enzyme property studies, the culture broth obtained from the fermentor was centrifuged at $1,650 \times g$ for $30 \mathrm{~min}$. Then, cold acetone was added to the supernatant to a final concentration of $80 \%(\mathrm{v} / \mathrm{v})$ followed by standing overnight. ${ }^{18)}$ The precipitate formed was collected by centrifugation at $6,580 \times g$ for $30 \mathrm{~min}$, washed twice with cold acetone and then recentrifuged. The final precipitate was dried under vaccum. The acetone powder obtained was used for further studies.

Chemicals. Olive oil was a product of Nippon Shinyaku Co., Ltd., (Japan). Almost all the reagents used were purchased from Katayama Chemical Co., Ltd., (Japan), except Emulgen 123P which was a product of Kao Chemicals (Tokyo, Japan). Corn steep liquor was obtained from Sanwa Denpun Industry Co., Ltd., (Japan). Sorbitol dehydrogenase was a product of Boehringer Mannheim Biochemica (FRG). Other chemicals were from commercial sources.

\section{RESULTS AND DISCUSSION}

\section{Screening for potent producers of lipase}

In the screening test performed on 20 thermophilic fungi, 3 strains of $H$. lanuginosa were found to be capable of producing lipolytic enzymes. However, these strains differed in the extent of enzyme production, the zones of hydrolysis being about $17 \sim 23 \mathrm{~mm}$ with the tributyrin agar method (data not shown). Among them, $H$. lanuginosa No. 3 showed the highest activity, and so it was used throughout subsequent experiments. Other strains of $H$. lanuginosa were also found to be potent lipase producers. $^{9,19)}$

\section{Medium optimization}

Effect of carbon sources. It was suggested that the lipase formed might be derived from carbohydrates in the medium with small quantities of lipid materials as inducer. ${ }^{4,12)}$ Hence various carbohydrates were tested, at $1.0 \%$ $(\mathrm{w} / \mathrm{v})$, in place of olive oil in the basal medium. As shown in Table I, sorbitol was found to be a better alternative to olive oil compared to the other sugars.

Effect of nitrogen sources. In this test, the medium used consisted of $(\%, \mathrm{w} / \mathrm{v})$ : sorbitol, 1.0; various nitrogen compounds, $1.0 ; \mathrm{NaCl}$, $0.5 ; \mathrm{CaCl}_{2} \cdot 2 \mathrm{H}_{2} \mathrm{O}, 0.01$; and Tween $80,0.3$ (pH 7.0) After 48-hr cultivation in Sakaguchi flasks, lipase production was stimulated with organic nitrogen sources, being $63.0 \mathrm{U} / \mathrm{ml}$ with corn steep liquor, $51.1 \mathrm{U} / \mathrm{ml}$ with peptone and $45.9 \mathrm{U} / \mathrm{ml}$ with yeast extract in contrast with about $30 \sim 35 \mathrm{U} / \mathrm{ml}$ with ammonium salts. Alcaligenes sp. ${ }^{18)}$ preferably utilized inorganic nitrogen sources for the enzyme production. In conclusion, corn steep liquor $(1.0 \%, \mathrm{v} / \mathrm{v})$ was found to be a good nitrogen source for lipase production by $H$. lanuginosa No. 3 .

Effect of minerals. The presence of $\mathrm{Ca}^{2+}$ in the cultivation medium was shown to stimulate lipase activity. ${ }^{20)}$ Various minerals $(0.01 \%$, w/v) were tested in comparison to $\mathrm{Ca}^{2+}$. As a result, $\mathrm{CaCl}_{2} \cdot 2 \mathrm{H}_{2} \mathrm{O}$ was expectedly found to be the most effective, enhancing the enzyme production to about $59.7 \mathrm{U} / \mathrm{ml}$ compared to 
Table I. Effect of Carbon Sources on Lipase Production By Humicola lanuginosa No. 3

\begin{tabular}{lc}
$\begin{array}{l}\text { Carbon sources } \\
(1.0 \%, \mathrm{w} / \mathrm{v})\end{array}$ & $\begin{array}{c}\text { Lipase activity } \\
(\mathrm{U} / \mathrm{ml})\end{array}$ \\
\hline Arabinose & 38.9 \\
Rhamnose & 36.3 \\
Sucrose & 19.6 \\
Fructose & 17.8 \\
Mannose & 29.7 \\
Xylose & 20.4 \\
Maltose & 15.9 \\
Galactose & 19.6 \\
Glucose & 32.6 \\
Trehalose & 27.8 \\
Sorbitol & 45.6 \\
Mannitol & 30.0 \\
Soluble starch & 18.9 \\
\hline
\end{tabular}

Medium: $1.0 \%$ of yeast extract, $0.5 \%$ of $\mathrm{NaCl}, 0.01 \%$ of $\mathrm{CaCl}_{2} \cdot 2 \mathrm{H}_{2} \mathrm{O}, 0.3 \%$ of Tween 80 and $1.0 \%$ of carbon source (Olive oil basal medium: $43.3 \mathrm{U} / \mathrm{ml}$ ). Cultivation conditions: $45^{\circ} \mathrm{C}, 48 \mathrm{hr}$.

Table II. Stimulation of Lipase Formation, on the AdDition of Natural Fats and Oils, GlyCERIDES, FATTY ACIDS AND OTHER Related Materials, BY Humicola lanuginosa No. 3

a) Natural fats and oils

\begin{tabular}{lclc}
\hline Fats/oils & $\begin{array}{c}\text { Lipase } \\
\text { act. } \\
(\mathrm{U} / \mathrm{ml})\end{array}$ & Fats/oils & $\begin{array}{c}\text { Lipase } \\
\text { act. } \\
(\mathrm{U} / \mathrm{ml})\end{array}$ \\
\hline Olive oil & 80.0 & Whale oil & 96.7 \\
Palm oil & 46.7 & Peanut oil & 80.0 \\
Coconut oil & 68.3 & Corn oil & 66.6 \\
Beef tallow & 60.0 & Tung oil & 86.7 \\
Lard & 51.7 & Soybean oil & 58.3 \\
Cottonseed oil & 68.3 & Eucalyptus oil* & 45.0 \\
Castor oil & 98.3 & & \\
\hline
\end{tabular}

the control $(23.3 \mathrm{U} / \mathrm{ml})$. Other minerals, $\mathrm{Fe}^{3+}$, $\mathrm{Mn}^{2+}$ and $\mathrm{Sn}^{2+}$, were also effective, the lipase production reaching about 53.5, 58.2 and 45.6 $\mathrm{U} / \mathrm{ml}$, while $\mathrm{Fe}^{2+}, \mathrm{Zn}^{2+}, \mathrm{Cu}^{2+}$ and $\mathrm{Co}^{2+}$ were not effective, the levels only being 11.9, 15.7, 5.6 and $7.8 \mathrm{U} / \mathrm{ml}$ of activity, respectively.

Stimulation of lipase formation by fatty substances

Basically, the presence of lipid materials in b) Triglycerides, monoesters and fatty acids.

\begin{tabular}{lccc}
\hline \multirow{2}{*}{$\begin{array}{c}\text { Added lipid } \\
\text { (carbon }\end{array}$} & \multicolumn{3}{c}{ Lipase activity $(\mathrm{U} / \mathrm{ml})$} \\
\cline { 2 - 4 } & Triglycerides & Monoesters & Fatty acids \\
\hline C2 & 83.3 & 75.0 & 40.0 \\
C4 & 13.3 & 48.3 & 30.0 \\
C5 & ND & ND & 41.7 \\
C6 & 36.7 & 40.0 & 22.0 \\
C8 & 23.3 & 58.3 & 35.0 \\
C10 & 3.3 & 60.0 & 31.0 \\
C12 & 33.3 & 53.3 & 25.0 \\
C14 & $46.7^{*}$ & $53.3^{*}$ & $66.7^{*}$ \\
C16 & $60.0 *$ & $48.3^{*}$ & $71.7 *$ \\
C18 & 65.0 & 66.6 & 50.2 \\
C18:1 & 71.7 & 75.0 & 41.7 \\
C18:2 & ND & 55.0 & 53.3 \\
C18:3 & ND & 55.0 & ND \\
C20 & ND & ND & 58.3 \\
Elaidic acid & - & - & 36.7 \\
\hline
\end{tabular}

c) Other related materials

\begin{tabular}{|c|c|c|c|}
\hline $\begin{array}{l}\text { Added } \\
\text { materials }\end{array}$ & $\begin{array}{c}\text { Lipase } \\
\text { act. } \\
(\mathrm{U} / \mathrm{ml})\end{array}$ & $\begin{array}{c}\text { Added } \\
\text { materials }\end{array}$ & $\begin{array}{c}\text { Lipase } \\
\text { act. } \\
(\mathrm{U} / \mathrm{ml})\end{array}$ \\
\hline Lecithin (egg)* & 55.0 & Oleyl alcohol & 58.3 \\
\hline $\begin{array}{l}\text { Lecithin } \\
\quad \text { (soybean)* }\end{array}$ & 75.0 & $\begin{array}{l}\text { Lauryl alcohol } \\
\text { Glycerol }\end{array}$ & $\begin{array}{l}38.3 \\
65.0\end{array}$ \\
\hline Cholesterol* & 75.0 & $n$-Hexyl OH & 61.7 \\
\hline Saponin* & 66.6 & $n$-Octyl OH & 40.0 \\
\hline Linalool & 83.3 & $n$-Decyl OH & 53.3 \\
\hline Geraniol & 61.7 & $n$-Hexadecane & 58.3 \\
\hline Brij 58* & 40.0 & Trimethylene & 73.3 \\
\hline Brij $35^{*}$ & 36.7 & glycol & \\
\hline Kerosene & 66.7 & Diethylene glycol & 50.0 \\
\hline$n$-Paraffin & 58.3 & Propylene glycol & 51.7 \\
\hline Emulgen $123-\mathrm{P}^{*}$ & 38.3 & Triton-X-100 & 12.0 \\
\hline
\end{tabular}

Medium: (see Fig. 1) all the substances were added at $0.3 \%, \mathrm{v} / \mathrm{v}$ or $\mathrm{w} / \mathrm{v}^{*}$. ND: not determined. Cultivation conditions: $45^{\circ} \mathrm{C}, 48 \mathrm{hr}$.

the cultivation medium remarkably stimulates the lipase production. ${ }^{6,13)}$ A similar phenomenon was also observed in H. lanuginosa No. 3, in that the lipase formation almost completely ceased in the absence of lipid material (less than $10 \mathrm{U} / \mathrm{ml}$ of activity), whereas inducible lipase formation was distinctly observed with the addition of Tween 80 , the level increasing to about $60 \mathrm{U} / \mathrm{ml}$. No significant change was seen in the cell mass on cultivation with or 
without the addition of Tween 80 , i.e., 8.1 with and $7.8 \mathrm{~g} / 1$ dry weight without the addition of Tween 80 .

Besides Tween 80, other lipid materials also caused significant stimulation of lipase formation. The stimulation efficiency of other fatty substances is shown in Table II. Natural fats such as castor oil, whale oil and tung oil stimulated the lipase formation (see Table IIa). Triacetin was also found to cause significant stimulation, while oleic acid showed an average stimulatory effect and elaidic acid, a streoisomer of oleic acid, showed a lower effect than oleic acid (see Table IIb). Phospholipids, alcohols (including terpene alcohols) and glycols were also found to be effective (see Table IIc).

The effect of the concentration of fatty substances such as castor oil, whale oil, tung oil, triacetin, cholesterol and lecithin (from soybean), in the lipase formation was investigated $(0.1,0.3$ and $0.5 \%)$. As a result, $0.3 \%$ addition was found to be the most effective, being slightly better than $0.1 \%$ addition, while $0.5 \%$ addition was the least effective for lipase formation.

\section{$C N$ ratio lipase production}

The effect of the concentration ratio of sorbitol ( 0 to $2.0 \%, \mathrm{w} / \mathrm{v})$ to corn steep liquor on the lipase production by $H$. lanuginosa No. 3 was investigated in aerobic cultures (shake flask, $\left.45^{\circ} \mathrm{C}\right)$ using Tween $80(0.3 \%, \mathrm{v} / \mathrm{v})$ as an inducer. The results indicated that a sorbitol concentration of between 1.0 and $1.5(\%)$ gave maximum lipase activity of about $70 \sim 80$ $\mathrm{U} / \mathrm{ml}$, provided that the concentration of corn steep liquor was fixed at $1.0 \%$. With a sorbitol concentration of less than $0.75 \%$ or of more than $1.75 \%$, the lipase activity dropped to about $40 \sim 60 \mathrm{U} / \mathrm{ml}$ (data not shown).

In addition, prior to use a fermentor for the lipase production, a suitable antifoamer that does not affect the enzyme production was selected from among several antifoamers (Silicone Km-70, Adekanol LG-109, Antifoam-AF-Emulsion and Antifoam-DBEmulsion) (data nto shown). The medium composition of $(\%, \mathrm{w} / \mathrm{v})$ : sorbitol, 1.0 ; corn steep liquor, $1.0 ; \mathrm{NaCl}, 0.5 ; \mathrm{CaCl}_{2} \cdot 2 \mathrm{H}_{2} \mathrm{O}$, 0.01 ; Tween $80,0.3(\mathrm{pH} \mathrm{7.0)}$, with Silicone $\mathrm{Km}-70$ at the concentration of $0.2 \%(\mathrm{v} / \mathrm{v})$ effectively prevented foam formation throughout the fermentation without causing any change in the enzyme production. Thus, $0.2 \%$ (v/v) Silicone $\mathrm{Km}-70$ was used in subsequent experiments.

\section{Effects of medium $p H$ and cultivation tem- perature}

The effects of $\mathrm{pH}$ and temperature on the enzyme production were studied with the following medium composition $(\%)$ : sorbitol, 1.0; corn steep liquor, $1.0 ; \mathrm{NaCl}, 0.5 ; \mathrm{CaCl}_{2}$. $2 \mathrm{H}_{2} \mathrm{O}, 0.01$; Tween 80, 0.3; and Silicone $\mathrm{Km}-70,0.2(\mathrm{pH}$ 7.0). The initial $\mathrm{pH}$ was adjusted to between 5 to 10 and the culture temperature was maintained at between $28 \sim 55^{\circ} \mathrm{C}$. On 48 -hr shaking culture at $45^{\circ} \mathrm{C}$ with an initial $\mathrm{pH}$ of between 7 and 9, the yield was about $66.7 \sim 59.3 \mathrm{U} / \mathrm{ml}$, the final $\mathrm{pH}$ being $7.8 \sim 8.1$, whereas on cultivation at acidic $\mathrm{pH}$ $(5 \sim 6)$, the lipase activity dropped to about $25.2 \sim 30.3 \mathrm{U} / \mathrm{ml}$. At a temperature below or above $45\left(37\right.$ or $\left.55^{\circ} \mathrm{C}\right)$, at a $\mathrm{pH}$ between 7 and 9 , the decrease in the enzyme activity was three-fold when compared with at $45^{\circ} \mathrm{C}$. Therefore, the optimum initial $\mathrm{pH}$ and temperature for lipase production were determined to be 7.0 and $45^{\circ} \mathrm{C}$, respectively (data not shown).

\section{Time course of lipase production}

Lipase production was investigated in a 101 fermentor using Tween 80, whale oil or castor oil as an inducer. The results in Fig. 1 show that the enzyme production reached the maximum after about $30-\mathrm{hr}$ cultivation, the activity being $70 \mathrm{U} / \mathrm{ml}$ (Tween 80 ) and 120 $\mathrm{U} / \mathrm{ml}$ (castor oil), while in the case of whale oil, a level of about $90 \mathrm{U} / \mathrm{ml}$ was observed after more than 2-day cultivation. With Tween 80 , the enzyme production decreased gradually after the maximum level, while with whale oil (Fig. 1b), it increased until about 60-hr cultivation. Almost similar growth and $\mathrm{pH}$ profiles 


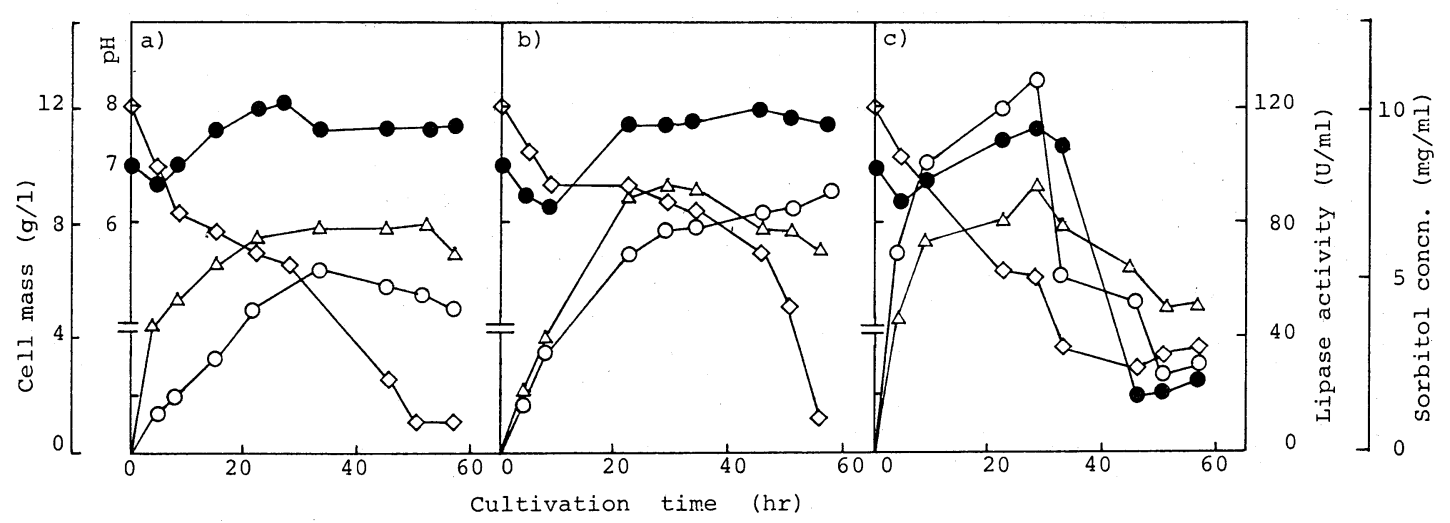

FIG. 1. Time Course of Lipase Production by H. lanuginosa No. 3 in a Fermentor.

Medium composition (\%): sorbitol, 1.0; corn steep liquor, $1.0 ; \mathrm{NaCl}, 0.5 ; \mathrm{CaCl}_{2} \cdot 2 \mathrm{H}_{2} \mathrm{O}, 0.01$; Silicone $\mathrm{Km}-70$, 0.2 ; and an inducer, (a) Tween 80 , (b) whale oil and (c) castor oil, 0.3 . Inoculum size: $4 \%$ (v/v).

$\bigcirc$, lipase activity; $\bigcirc, \mathrm{pH} ; \triangle$, growth; $\diamond$, sorbitol concentration.

were observed with Tween 80 and whale oil.

A different profile was observed with castor oil (see Fig. 1c). The enzyme production increased rapidly to the maximum level of about $120 \mathrm{U} / \mathrm{ml}$, however, a rapid drop was observed thereafter, which was probably due to a tremendous decrease in the $\mathrm{pH}$, from 7.5 to 1.0 , as observed in duplicate cultivations. The reason for this drop is not clear at present.

About $90 \%$ of the sorbitol was consumed throughout the cultivation with both Tween 80 and whale oil, whereas with castor oil, the consumption ceased immediately after the $\mathrm{pH}$ had dropped to 1.0 .

In conclusion, with the optimized medium $(1.0 \%$ corbitol, $1.0 \%$ corn steep liquor with $0.3 \%$ inducible substance), lipase production $(80 \sim 120 \mathrm{U} / \mathrm{ml})$ was possible on $25-\mathrm{hr}$ cultivation at $45^{\circ} \mathrm{C}$ with the $\mathrm{pH}$ maintained between 7 and 8 .

Some properties of the crude lipase preparation

In the previous work, ${ }^{14}$ only one kind of lipase was purified from $H$. lanuginosa No. 3, and the enzyme properties were fully analyzed by the usual methods. Here, the crude lipase (acetone powder) was subjected to enzyme property analysis in order to use it for practical applications.

(a) Effect of $p H$ and temperature on activity and stability. The crude lipase obtained in the fermentor experiment was investigated as to the optimum $\mathrm{pH}$ and its stability. As shown in Fig. 2, the enzyme was found to be most active at $\mathrm{pH} 7.0$ and the enzyme was stable at $\mathrm{pHs}$ between 5 and 9.5

Next, the optimum temperature for the enzyme activity was determined, reactions being performed at various temperatures, from 30 to 70 , for $30 \mathrm{~min}$. The optimum temperature was found to be $45^{\circ} \mathrm{C}$, about $80 \%$ of the relative activity being observed at $60^{\circ} \mathrm{C}$ (Fig. 3). The thermal stability was investigated by determining the residual activity after leaving the enzyme at various temperatures, between 30 to $100^{\circ} \mathrm{C}$, for $10 \mathrm{~min}$. The enzyme was stable up to $70^{\circ} \mathrm{C}$, i.e., it retained $100 \%$ activity, however, the activity decreased rapidly to $25 \%$ at $100^{\circ} \mathrm{C}$. Another thermal stability test was carried out at 60,65 and $70^{\circ} \mathrm{C}$, for a longer incubation time. As shown in Fig. 4, the enzyme retained $100 \%$ activity at $60^{\circ} \mathrm{C}$ for $20 \mathrm{hr}$ and at $65^{\circ} \mathrm{C}$ for $70 \mathrm{~min}$, and more than $75 \%$ of the activity was still observed at $70^{\circ} \mathrm{C}$ after $90 \mathrm{~min}$. Similar results were observed for Aspergillus niger ${ }^{1}$ (opt. temp., $25^{\circ} \mathrm{C}$; temp. stability, $55^{\circ} \mathrm{C}$ ) and Staphylococcus aureus $^{21)}$ (opt. temp., $45^{\circ} \mathrm{C}$; temp. stabillity, $65^{\circ} \mathrm{C}$ ).

The $\mathrm{pH}$ and temperature characteristics 


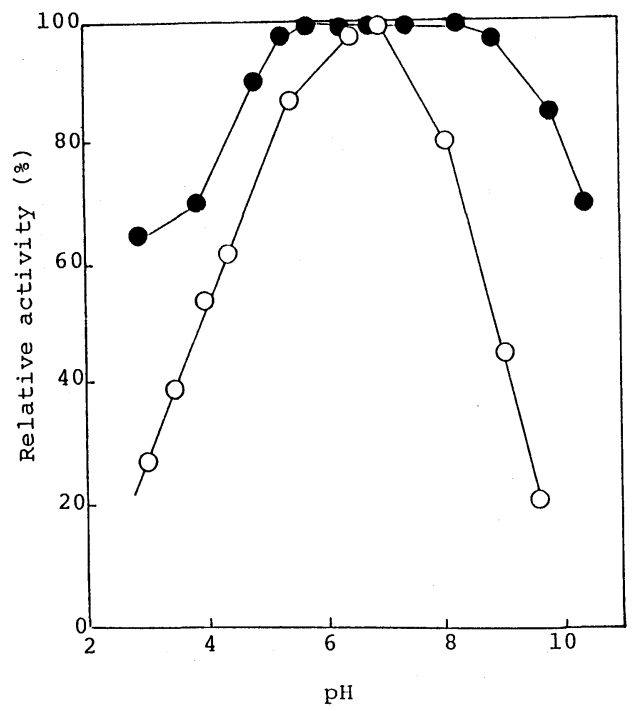

FIG. 2. pH Optimum and Stability of the Crude Lipase from $H$. lanuginosa No. 3.

The enzyme reaction was carried out at various $\mathrm{pHs}$. The activity was determined by the olive oil-PVA emulsion method. The buffer systems were $(0.2 \mathrm{M})$ : Mcllvaine buffer ( $\mathrm{pH} 3 \sim 7.5$ ), Atkins and Pantin buffer ( $\mathrm{pH} 8 \sim 11$ ) and $\mathrm{Na}_{2} \mathrm{HPO}_{4}-\mathrm{NaOH}(\mathrm{pH} 11 \sim 12$ ). Relative activity was calculated on the basis of the activity at $\mathrm{pH} 7.0 . \mathrm{pH}$ stability was measured as the residual enzyme activity after incubation at $45^{\circ} \mathrm{C}$ for $24 \mathrm{hr}$.

$\bigcirc, \mathrm{pH}$ optimum;, $\mathrm{pH}$ stability.

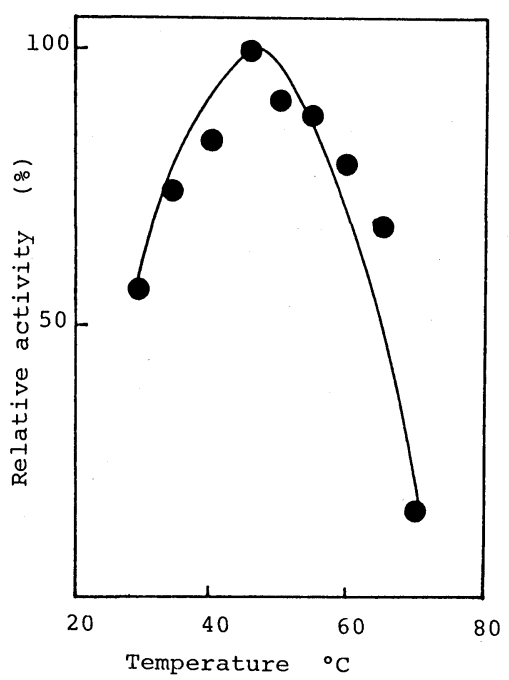

FIG. 3. Effect of Temperature on the Enzyme Activity.

The enzyme reaction was carried out at various temperatures. The activity was determined by the olive oil-PVA emulsion method. Relative activity was calculated on the basis of the activity at $45^{\circ} \mathrm{C}, \mathrm{pH} 7.0$.

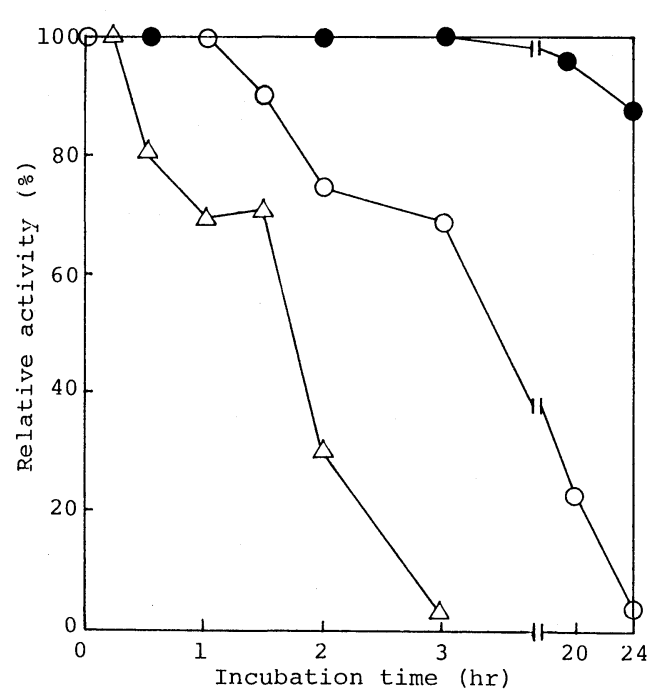

FIG. 4. Temperature Stability of the Crude Lipase from H. lanuginosa No. 3.

The enzyme-buffered solution ( $\mathrm{pH} 7.0$ ) was incubated for the indicated periods and then the residual activity was determined by the olive oil-PVA emulsion method.

$60^{\circ} \mathrm{C} ; \mathrm{O}, 65^{\circ} \mathrm{C} ; \triangle, 70^{\circ} \mathrm{C}$.

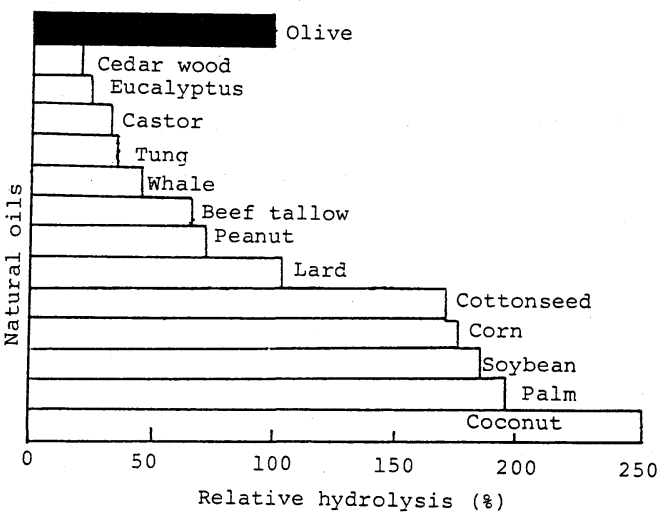

Fig. 5. Hydrolysis of Natural Fats by the Crude Lipase from $H$. lanuginosa No. 3.

Reaction conditions: $1.0 \mathrm{ml}$ of natural fat, $4.0 \mathrm{ml}$ of $0.2 \mathrm{M}$ phosphate buffer ( $\mathrm{pH} \mathrm{7.0)}$ and $1.0 \mathrm{ml}$ of enzyme solution $(40 \mathrm{U}), 45^{\circ} \mathrm{C}$ for $2 \mathrm{hr}$. Hydrolysis (\%) was calculated relative to the hydrolysis of olive oil, which was taken as $100 \%$.

were almost the same as those observed for the purified enzyme, ${ }^{14)}$ indicating that $H$. lanuginosa No. 3 might be a potential source of thermostable lipase for practical applications.

(b) Hydrolysis of natural fats. The hydrolyses of various natural fats with the crude 
lipase from $H$. lanuginosa No. 3 were carried out and the fatty acid liberated was measured. As shown in Fig. 5, the enzyme was capable of hydrolyzing broad range of substrates including most solid fats (beef tallow, lard, palm oil and coconut oil). Plant oils were found to be most rapidly hydrolyzed by the enzyme, while castor oil and tung oil were poorly hydrolyzed by the enzyme.

\section{REFERENCES}

1) J. Fukumoto, M. Iwai and Y. Tsujisaka, J. Gen. Appl. Microbiol., 9, 353 (1963).

2) J. Fukumoto, M. Iwai and Y. Tsujisaka, J. Gen. Appl. Microbiol., 10, 257 (1964).

3) K. Nagaoka, Y. Yamada and Y. Koaze, Agric. Biol. Chem., 33, 299 (1969).

4) Y. Minoda and Y. Ota, Microbial Utilization of Renewable Resources on Agro-Industry Microbial Technology, JSPS-NRCT, 1, 73 (1980).

5) Y. Kokusho, H. Machida and H. Iwasaki, Agric. Biol. Chem., 46, 1159 (1982).

6) Y. Ota, M. Suzuki and K. Yamada, Agric. Biol. Chem., 32, 390 (1968).

7) R. C. Lawrence, T. F. Fryeer and B. Reiter, J. Gen. Appl. Microbiol., 48, 401 (1967).

8) K. Aisaka and O. Terada, Agric. Biol. Chem., 43,
2125 (1967).

9) K. Arima, W. H. Liu and T. Beppu, Agric. Biol. Chem., 36, 1913 (1972).

10) N. Watanabe, Y. Ota, Y. Minoda and K. Yamada, Agric. Biol. Chem., 41, 1356 (1977).

11) J. B. M. Rattray, JAOCS, 61, 1701 (1984).

12) M. Iwai, Y. Tsujisaka, Y. Okamoto and J. Fukumoto, Agric. Biol. Chem., 37, 929 (1973).

13) Y. Kosugi and A. Kamibayashi, J. Ferment. Technol., 49, 968 (1971).

14) C. O. Ibrahim, M. Hayashi and S. Nagai, Agric. Biol. Chem., 51, 37 (1987).

15) R. C. Lawrence, T. F. Fryeer and B. Reiter, Nature, 25, 1264 (1967).

16) K. Yamada and H. Machida, Nippon Nōgeikagaku Kaishi, 36, 858 (1962).

17) H. U. Bergmeyer, "Methods of Enzymatic Analysis," Vol. 3, 2nd Ed., ed. by H. U. Bergmeyer, Academic Press Inc., New York and London, 1974, p. 1323.

18) Y. Kokusho, H. Machida and S. Iwasaki, Agric. Biol. Chem., 46, 1743 (1982).

19) T. Morinaga, S. Kanda and R. Nomi, J. Ferment. Technol., 64, 451 (1986).

20) Y. Ota and K. Yamada, Agric. Biol. Chem., 31, 809 (1967).

21) Y. Ota, "Handbook of Microbiology," Vol. 111, ed. by A. I. Laskin and H. A. Lechevalier, CRC Press, Inc., Cleveland, Ohio, 1973, p. 625. 